\title{
Determination of MIC, MPC, and MSW of Ilex paraguariensis Against Non-Typhoidal Salmonella with Identification of the Mechanisms of Resistance and Pathogenicity Factors
}

Khaled El Khatib

University of Balamand Faculty of Medicine and Medical Sciences

Ribal Aby Hadeer

University of Balamand Faculty of Medicine and Medical Sciences

Anis Saad

University of Balamand Faculty of Medicine and Medical Sciences

Aline Kalaydjian

University of Balamand Faculty of Medicine and Medical Sciences

Elie Fayad

University of Balamand Faculty of Sciences

Victorien Dougnon

Universite d'Abomey-Calavi Research Unit in Applied Microbiology and Pharmacology of Natural

Substances

Ziad Daoud

Michigan Health Clinics Department of Clinical Microbiology and Infection Prevention \& Central Michigan University College of Medicine

Roula M. Abdel-Massih ( $\nabla$ roula.abdelmassih@balamand.edu.lb )

University of Balamand https://orcid.org/0000-0003-1272-4746

Research note

Keywords: Salmonella, Virulence genes, Ilex paraguariensis, Antibacterial activity, Antimicrobial resistance

Posted Date: December 17th, 2020

DOl: https://doi.org/10.21203/rs.3.rs-127725/v1

License: (c) (1) This work is licensed under a Creative Commons Attribution 4.0 International License.

Read Full License 


\section{Abstract}

Objective: This study investigated the antibacterial activity of Ilex paraguariensis extracts against 32 different strains of non-typhoidal Salmonella (NTS) through the determination of the Minimum Inhibitory Concentration (MIC), Mutant Prevention Concentration (MPC), Mutant Selection Window (MSW), and the detection of virulence genes by multiplex PCR assays.

Results: The MIC values of Ilex paraguariensis against Salmonella spp. strains varied between 0.78 $\mathrm{mg} / \mathrm{ml}$ and $6.25 \mathrm{mg} / \mathrm{ml}$ with a MIC 90 of $3.12 \mathrm{mg} / \mathrm{ml}$. The highest MPC in this study was $48 \mathrm{mg} / \mathrm{ml}$ yielding a Mutant Selection Window of $41.75 \mathrm{mg} / \mathrm{ml}$. The MSW values of the remaining strains varied between 1.56 and $8.87 \mathrm{mg} / \mathrm{ml}$. Genes of pathogenicity detected in Salmonella spp. isolates were most commonly the stn, sdiA, invA, sopB, invH, and sopE genes. The antibacterial activity of Yerba Mate extracts was not affected by the antimicrobial resistance patterns or pathogenicity genes expressed. More work is needed to identify the active antibacterial compound(s) responsible for the antibacterial activity.

\section{Introduction}

Salmonella typhi- and Salmonella paratyphi-associated enteric fevers cause severe diseases, affecting mainly underdeveloped areas, while other non-typhoidal Salmonella (NTS) infections are more selflimiting but with a wide-reaching prevalence (Eng et al., 2015). Enteric fevers are major causes of morbidity and mortality (Sánchez-Vargas et al., 2011). Non-typhoidal Salmonella remains an important cause of morbidity with Salmonella enteritidis and Salmonella typhimurium being the most prevalent serotypes (Eng et al., 2015). NTS causes an estimated 93.8 million cases of acute gastroenteritis worldwide each year (Balasubramanian et al., 2019; Al-Rifai et al., 2020). NTS can be transmitted via food contaminated by animal feces (Crump et al., 2015). The severity of salmonellosis depends on the host and on the associated virulence factors that are controlled by chromosomal or plasmidic genes. Virulence genes can be found clustered together on 'pathogenicity islands' which are activated at a specific time during the course of infection. Thus, a single pathogenicity island can make a specific serotype pathogenic, such as the role of Salmonella pathogenicity island 1 (SPI-1) in the penetration of intestinal epithelial cells, the role of SPI 2, 3 and 4 in bacterial survival, and the role of SPI 5 in inflammation (Marcus et al., 2000).

In contrast to enteric fevers, gastroenteritis caused by NTS is usually a self-limiting infection that does not require antibiotic treatment. Furthermore, persistent digestive symptoms are more common among patients treated with antibiotics (9.5\%) as opposed to those not treated with antibiotics (2.9\%) (Giorgio, 2000). However, antibiotics become necessary in case of complications, such as meningitis and septicemia (Medalla et al., 2017). Unfortunately, decades of use of these antibiotics resulted in the emergence of multi-drug resistant Salmonella, resulting in increased mortality. 
Ilex paraguariensis, known as Yerba mate (YM), is a plant originally from South America's subtropical region. YM is considered as an alternative to coffee and tea and is consumed by millions of people worldwide. There are different bioactive compounds in YM leaves associated with many health benefits including antioxidant properties, hypoglycemic effects, fat loss properties and most importantly its antimicrobial activity (Bastos et al., 2007; Fayad et al., 2020; Kungel et al., 2018; Noureddine et al., 2018).

The aim of this study was to evaluate the antimicrobial activity of YM extracts against non-typhoidal Salmonella isolates through the determination of the Minimum Inhibitory Concentrations (MIC), Mutant Prevention Concentration and Mutant Selection Window (MPC and MSW), and the detection of virulence genes by multiplex-PCR assay.

\section{Materials And Methods}

Bacterial strains and antibiotic susceptibility: Thirty-two clinical isolates of Salmonella spp. were isolated from Lebanese and Beninese patients. Salmonella isolates were identified using API 20E system (Biomérieux, France) after isolation on Salmonella Shigella agar (SS) (Biorad- Germany). Antibiotic Susceptibility Testing was performed using the Kirby Bauer technique with different antibiotics disks (Biorad, Germany). The results were interpreted according to EUCAST guidelines (2017). The susceptibility of the isolates to colistin was determined using the Microdilution method (CLSI, 2018)

\section{Phenotypic detection of ESBLand AmpC}

Phenotypic detection of extended spectrum beta-lactamase (ESBL) producing bacteria and AmpC betalactamases were performed as explained in Dandachi et al. (2018) using the double-disk synergy test or the cefoxitin disk test (Black et al., 2005) respectively. For the detection of carbapenemases, the carba NP test was used as per the manufacturer instructions (Cunningham et al., 2017) to distinguish between KPC, Oxa-48, VIM, IMP, and NDM.

\section{Molecular characterization of beta-Lactamase encoding genes}

Isolates that showed cefoxitin resistance or a keyhole effect were further studied using real-time PCR as detailed in Dandachi et al. (2018). Briefly, DNA was extracted from isolates using EZ1 DNA extraction kits (Qiagen, France) and real-time PCR was used for the detection of CTX-M, TEM, SHV, and other resistance genes (Roschanski et al., 2014).

\section{Determination of the Minimum Inhibitory Concentration}

The Minimum Inhibitory Concentration (MIC) was performed using broth microdilution method as described in the Clinical and Laboratory Standards Institute (CLSI, 2018). Briefly the highest concentration of the antimicrobial agent was added to the first well of a 96-well plate and a serial dilution was performed. A volume of $100 \mu \mathrm{l}$ of a $10^{6} \mathrm{CFU} / \mathrm{ml}$ bacterial suspension was dispensed into all the wells except for the negative control. The plate was incubated overnight and MIC was recorded as the 
concentration of the first well that shows no bacterial growth. MIC 90 is defined as the lowest concentration of the extract at which $90 \%$ of the bacterial isolates were inhibited.

\section{Mutant Prevention Concentration}

The Mutant Prevention Concentration (MPC) was determined using the agar plate dilution method as described by Pasquali \& Manfreda (2007). Briefly, the antimicrobial agents were incorporated into Mueller Hinton Agar (MHA) plates to create a concentration gradient from 1000-0.1 $\mu \mathrm{g} / \mathrm{ml}$. The bacterial suspension was then concentrated to $10^{10} \mathrm{CFU} / \mathrm{ml}$ and inoculated on the entire range of antibiotic containing MHA plates. The plates were incubated and the concentration of the first plate that showed no growth after 48 hours was considered as the MPC. All the tests were performed in duplicate.

\section{Detection of virulence genes by Polymerase Chain Reaction.}

Salmonella strains was cultured overnight at $37^{\circ} \mathrm{C}$ in brain heart infusion broth (Oxoid, United Kingdom). An aliquot of $1 \mathrm{ml}$ of each bacterial culture was separated for DNA extraction by heat treatment (Borges et al., 2013). The PCR experiments were conducted in individual reactions using primers for the following genes: sdiA, invA, sopB, invH, sopE, pefA, and sefC (Choudhury et al., 2016). The cycling program was performed in the CFX-96 thermal cycler (BioRad, Germany). The amplified products were separated by electrophoresis in a $1.2 \%$ agarose gel and stained with ethidium bromide. Fragments were transilluminated with UV light. E. coli ATCC 25922 (stn -ve) and S. enteritidis ATCC 13076 (stn +ve) were used as negative and positive controls respectively for all PCR reactions. A control containing the PCR mix without extracted DNA was also added in all PCR runs. All isolates having colistin MIC $>2 \mathrm{mg} / \mathrm{ml}$ were subjected to standard PCR for the detection of mcr-1 colistin resistant gene (Rebelo et al. (2018).

\section{Aqueous YM Extraction}

Commercial YM dried leaves (brand AMANDA) were purchased from the local market and an aqueous extraction was performed as explained in Noureddine et al. (2018). In brief, the leaves were blended and mixed with distilled water at a ratio of $3.6: 1 \mathrm{ml} / \mathrm{g}$. The mixture was heated at $70^{\circ} \mathrm{C}$ for 2 hours. Extracts were filtered using Whatman ( $1 \mathrm{M})$ filter papers, dialyzed against distilled water for 48 hours, centrifuged at 3325 G, concentrated using a SpeedVacuum concentrator (Thermo Fisher Scientific, USA), and stored at $4{ }^{\circ} \mathrm{C}$.

\section{Results}

The MIC values of Ilex paraguariensis against Salmonella spp. strains varied between $0.78 \mathrm{mg} / \mathrm{ml}$ and $6.25 \mathrm{mg} / \mathrm{ml}$ with a MIC 90 of $3.12 \mathrm{mg} / \mathrm{ml}$ (Table 1). ESBL strains had MIC values of $0.78 \mathrm{mg} / \mathrm{ml}$ and $1.56 \mathrm{mg} / \mathrm{ml}$ (Table 1). All Salmonella strains manifested full susceptibility to carbapenems (ertapenem, imipenem) and trimethoprim-sulfamethoxazole. However, only $84 \%$ were susceptible to 3rd generation cephalosporins (cefotaxime and ceftazidime) and $69 \%$ were susceptible to ampicillin (Table S1). The phenotypic and genotypic mechanisms of resistance to beta-lactam antibiotics as well as the presence of 
mcr-1 responsible for resistance to colistin in Salmonella spp. isolates were studied (Table 2). Five isolates were associated with the production of at least one ESBL gene. Of these isolates, four produced 2 types of ESBL genes, one produced all ESBL genes (TEM, SHV, and CTX-M). All five isolates gave a positive ESBL phenotypic test showing synergy between clavulanic acid and at least one of the three 3rd generation cephalosporins tested. TEM and SHV genes were found in $9.4 \%$ and $12.5 \%$ of the Salmonella strains accounting for $40 \%$ and $80 \%$ respectively of ESBL producing strains. CTX-M was consistently present in all ESBL producing isolates (isolates 41, 51, 61, 62, 65). All Salmonella isolates tested were susceptible to colistin antibiotic with MIC 90 of $0.25 \mathrm{mg} / \mathrm{l}$ and mcr-1 gene was not detected (Table 2). 
Table 1

Minimum Inhibitory Concentrations of Ilex paraguariensis against different strains of nontyphoidal Salmonella. Mutant Prevention Concentration (MPC) and Mutant Selection Window (MSW) of YM were studied on selected Salmonella spp. isolates (strain numbers 11, 20, 34, $35,51,56,59,60,65)$.

\begin{tabular}{|c|c|c|c|}
\hline $\begin{array}{l}\text { Salmonella } \\
\text { Strain Number }\end{array}$ & $\mathrm{MIC}(\mathrm{mg} / \mathrm{ml})$ & $\begin{array}{l}\text { MPC } \\
(\mathrm{mg} / \mathrm{ml})\end{array}$ & $\begin{array}{l}\text { MSW } \\
(\mathrm{mg} / \mathrm{ml})\end{array}$ \\
\hline 1 & 3.12 & & \\
\hline 4 & 1.56 & & \\
\hline 11 & 3.12 & 12 & 8.87 \\
\hline 12 & 3.12 & & \\
\hline 14 & 1.56 & & \\
\hline 17 & 3.12 & & \\
\hline 20 & 1.56 & 6.25 & 4.69 \\
\hline 22 & 3.12 & & \\
\hline 26 & 3.12 & & \\
\hline 29 & 1.56 & & \\
\hline 32 & 1.56 & & \\
\hline 33 & 0.78 & & \\
\hline 34 & 1.56 & 3.25 & 1.69 \\
\hline 35 & 1.56 & 6.25 & 4.69 \\
\hline 36 & 0.78 & & \\
\hline 38 & 3.12 & & \\
\hline $41^{*}$ & 0.78 & & \\
\hline 45 & 1.56 & & \\
\hline 49 & 3.12 & & \\
\hline 50 & 1.56 & & \\
\hline $51^{*}$ & 0.78 & 3.12 & 2.34 \\
\hline 52 & 1.56 & & \\
\hline 54 & 1.56 & & \\
\hline
\end{tabular}

* ESBL producing strain; ** MIC 90 is the concentration at which $90 \%$ of the strains MIC lie. 


\begin{tabular}{|llll|}
\hline $\begin{array}{l}\text { Salmonella } \\
\text { Strain Number }\end{array}$ & MIC $(\mathrm{mg} / \mathrm{ml})$ & $\begin{array}{l}\text { MPC } \\
(\mathrm{mg} / \mathrm{ml})\end{array}$ & $\begin{array}{l}\text { MSW } \\
(\mathrm{mg} / \mathrm{ml})\end{array}$ \\
\hline 55 & 0.78 & & 1.56 \\
\hline 56 & 1.56 & 3.12 & 1.56 \\
\hline 59 & 1.56 & 48 & 41.75 \\
\hline 60 & 6.25 & & \\
\hline $61 *$ & 0.78 & & 1.56 \\
\hline $62 *$ & 0.78 & 3.12 & \\
\hline 64 & 1.56 & & \\
\hline $65 *$ & 1.56 & & \\
\hline 66 & 3.12 & & \\
\hline MIC $90^{* *}$ & 3.12 & & \\
\hline$*$ ESBL producing strain; **MIC 90 is the concentration at which $90 \%$ of the strains MIC lie. & \\
\hline
\end{tabular}


Table 2

Phenotypic and genotypic mechanisms of resistance to beta-lactam antibiotics and colistin in Salmonella spp. isolates.

\begin{tabular}{|c|c|c|c|c|c|c|}
\hline \multirow[b]{3}{*}{$\begin{array}{l}\text { Salmonella } \\
\text { Strain }\end{array}$} & \multicolumn{4}{|c|}{ Resistance to Beta-Lactams } & \multicolumn{2}{|c|}{ Resistance to Colistin } \\
\hline & \multicolumn{3}{|c|}{$\begin{array}{l}\text { Genes of resistance } \\
\text { detected by PCR }\end{array}$} & \multirow{2}{*}{$\begin{array}{l}\text { Phenotypic } \\
\text { resistance } \\
\text { ESBL }\end{array}$} & \multirow{2}{*}{$\begin{array}{l}\text { Gene of } \\
\text { resistance } \\
\text { mcr-1 }\end{array}$} & \multirow{2}{*}{$\begin{array}{l}\text { Phenotypic } \\
\text { resistance } \\
\text { MIC mg/l }\end{array}$} \\
\hline & TEM & SHV & CTX-M & & & \\
\hline 1 & - & - & - & - & - & $0.12(S)$ \\
\hline 4 & - & - & - & - & - & $0.25(S)$ \\
\hline 11 & - & - & - & - & - & $0.5(S)$ \\
\hline 12 & - & - & - & - & - & $0.06(S)$ \\
\hline 14 & - & - & - & - & - & $0.12(\mathrm{~S})$ \\
\hline 17 & - & - & - & - & - & $0.06(S)$ \\
\hline 20 & - & - & - & - & - & $0.06(S)$ \\
\hline 22 & - & - & - & - & - & $0.06(S)$ \\
\hline 26 & + & - & - & - & - & $0.25(S)$ \\
\hline 29 & - & - & - & - & - & $0.06(S)$ \\
\hline 32 & - & - & - & - & - & $0.06(S)$ \\
\hline 33 & - & - & - & - & - & $0.25(\mathrm{~S})$ \\
\hline 34 & - & - & - & - & - & $0.12 v(S)$ \\
\hline 35 & - & - & - & - & - & $0.12(\mathrm{~S})$ \\
\hline 36 & - & - & - & - & - & $0.03(\mathrm{~S})$ \\
\hline 38 & - & - & - & - & - & $0.5(\mathrm{~S})$ \\
\hline 41 & - & + & + & + & - & $0.03(S)$ \\
\hline 45 & - & - & - & - & - & $0.12(\mathrm{~S})$ \\
\hline 49 & - & - & - & - & - & $0.06(S)$ \\
\hline 50 & - & - & - & - & - & $0.06(S)$ \\
\hline 51 & + & + & + & + & - & $0.06(S)$ \\
\hline 52 & - & - & - & - & - & $0.12(S)$ \\
\hline
\end{tabular}

S: susceptible; MIC 90 is the concentration at which $90 \%$ of the strains MIC lie. 


\begin{tabular}{|c|c|c|c|c|c|c|}
\hline \multirow[b]{2}{*}{54} & \multicolumn{4}{|c|}{ Resistance to Beta-Lactams } & \multicolumn{2}{|c|}{ Resistance to Colistin } \\
\hline & - & - & - & - & - & $0.06(S)$ \\
\hline 55 & - & - & - & - & - & $0.12(S)$ \\
\hline 56 & - & - & - & - & - & $0.12(S)$ \\
\hline 59 & - & - & - & - & - & $0.06(S)$ \\
\hline 60 & - & - & - & - & - & $0.03(S)$ \\
\hline 61 & + & - & + & + & - & $0.25(S)$ \\
\hline 62 & - & + & + & + & - & $0.25(\mathrm{~S})$ \\
\hline 64 & - & - & - & - & - & $0.03(\mathrm{~S})$ \\
\hline 65 & - & + & + & + & - & $0.12(\mathrm{~S})$ \\
\hline 66 & - & - & - & - & - & $0.03(\mathrm{~S})$ \\
\hline Positivity & $9.4 \%$ & $12.5 \%$ & $15.6 \%$ & $15.6 \%$ & $0 \%$ & MIC $90=0.25$ \\
\hline
\end{tabular}

The Mutant Prevention Concentrations of Ilex paraguariensis against non-typhoidal Salmonella isolates were studied on selected Salmonella spp. isolates (Table 1). The highest MPC found in this study is that of strain $60(48 \mathrm{mg} / \mathrm{ml})$ yielding a Mutant Selection Window of $41.75 \mathrm{mg} / \mathrm{ml}$. The MSW values of the remaining strains varied between $1.56-8.87 \mathrm{mg} / \mathrm{ml}$. Table 3 shows the different pathogenicity genes detected in Salmonella isolates. Most commonly, the genes stn, sdiA, invA, sopB, invH, and sopE were detected. Twenty-eight isolates (87.5\%) were associated with the detection of more than one gene of resistance. Stn gene was found in all the isolates and was followed by the gene sdiA with $81.2 \%$ of detection rate (Table 3 ). 
Table 3

Genes of pathogenicity detected in Salmonella isolates studied. PCR experiments were conducted using primers for stn, sdiA, invA, sopB, invH, sopE, pefA, and sefC. The amplified products were separated by electrophoresis in a 1.2\% agarose gel and stained with ethidium bromide.

\begin{tabular}{|c|c|c|c|c|c|c|c|c|c|}
\hline & Serotypes & Gen & & & & & & & \\
\hline Strain & & Stn & sdiA & $\operatorname{inv} A$ & sopB & invH & sopE & pefA & sefC \\
\hline 1 & S. enteritidis & + & + & + & + & + & + & - & - \\
\hline 4 & S. enteritidis & + & + & + & + & + & + & - & - \\
\hline 11 & S. enteritidis & + & - & + & + & + & + & - & - \\
\hline 12 & S. enteritidis & + & + & + & + & + & + & - & - \\
\hline 14 & S. enteritidis & + & + & - & - & + & + & - & - \\
\hline 17 & S. enteritidis & + & + & + & + & + & + & - & - \\
\hline 20 & S. enteritidis & + & + & + & + & + & + & - & - \\
\hline 22 & S. enteritidis & + & - & + & + & + & + & - & - \\
\hline 26 & S. enteritidis & + & + & + & + & + & + & - & - \\
\hline 29 & S. enteritidis & + & + & - & - & + & + & - & - \\
\hline 32 & S. typhimurium & + & + & - & - & + & + & - & - \\
\hline 33 & S. enteritidis & + & + & + & + & + & + & - & - \\
\hline 34 & S. enteritidis & + & + & - & - & - & - & - & - \\
\hline 35 & S. enteritidis & + & + & - & - & - & - & - & - \\
\hline 36 & S. enteritidis & + & + & - & - & - & - & - & - \\
\hline 38 & S. corvalis & + & - & - & - & - & - & - & - \\
\hline 41 & S. enteritidis & + & + & - & - & - & - & - & - \\
\hline 45 & S. enteritidis & + & + & - & - & - & - & - & - \\
\hline 49 & S. enteritidis & + & + & - & - & - & - & - & - \\
\hline 50 & S. enteritidis & + & + & - & - & - & - & - & - \\
\hline 51 & S. enteritidis & + & + & - & - & - & - & - & - \\
\hline 52 & S. enteritidis & + & + & - & - & - & - & - & - \\
\hline 54 & S. enteritidis & + & - & - & - & - & - & - & - \\
\hline 55 & S. enteritidis & + & + & - & - & - & - & - & - \\
\hline
\end{tabular}




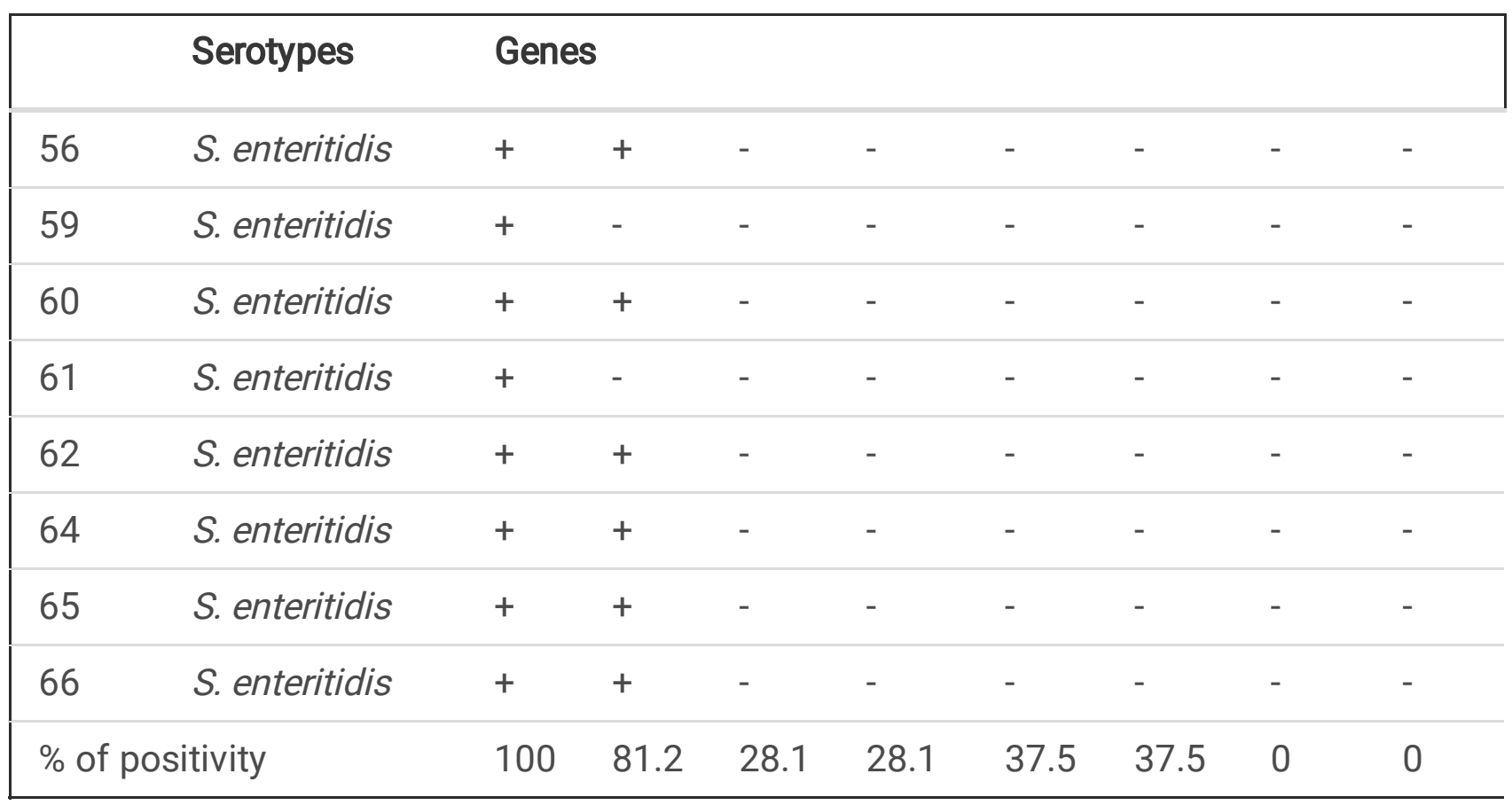

\section{Discussion}

Non-typhoidal Salmonella infections are a major cause of diarrhea, they can even cause serious invasive salmonellosis (Wen et al., 2017). Ilex paraguariensis is popularly consumed in many countries and is rich in different bioactive compounds such as purine alkaloids, phenolic compounds, and saponins (Bastos et al., 2007). In the present work, YM extracts had an antibacterial activity against different Salmonella spp. with MIC between $0.78-3.12 \mathrm{mg} / \mathrm{ml}$. Similarly, YM hexane and ethanol extracts showed antibacterial activity against $S$. typhimurium with MICs of 0.58 and $1.14 \mathrm{mg} / \mathrm{ml}$ respectively (Vieitez et al., 2018). Kungel et al. (2018) isolated a polysaccharide from YM with antibacterial activity against $S$. enteritidis and S. typhimurium (MIC $0.4 \mathrm{mg} / \mathrm{ml}$ ).

YM ethanolic extracts (richer in phenolic content) were more effective against $S$. enteritidis than methanolic extracts with MICs 3.13 and $6.25 \mathrm{mg} / \mathrm{ml}$ respectively (Martin et al., 2013). Although studies suggest better potency of YM on gram-positive bacteria, the hexane and aqueous extracts of YM had MIC $50-200 \mu \mathrm{g} / \mathrm{ml}$ on different gram-negative bacteria (Penteado et al., 2016). The aqueous extract of YM (at $64 \mathrm{mg} / \mathrm{ml}$ ) significantly inhibited the growth of Salmonella enterica (Rempe, 2016). YM had bacteriostatic and bactericidal activities against different serovars of Salmonella spp. with MICs 150-200 mg/ml (De Bona et al., 2010). S. enteritidis was the most sensitive among different bacteria studied with inhibition (value 8) (Girolometto et al., 2009).

Mutant Selection Window (MSW) corresponds to the danger zone of drug concentration in which the bacterium can undergo a mutation that enables it to become phenotypically resistant to that drug and to show clinical failure. Subsequently, the smaller the value of the MSW, the better is the prognosis of the treatment. YM manifested a relatively narrow MSW that was a multiple of 2 or 3 of the MIC (Table 1). The genotypic and phenotypic mechanisms of resistance of Salmonella isolates tested here did not correlate with a special resistance to commonly used antibiotics. ESBL producing strains were not correlated with 
the highest resistance to YM. Furthermore, among the Salmonella isolates that showed more than 2 virulence genes, none showed a higher MIC as compared to the rest of the strains, suggesting therefore that no relationship between these two parameters exist.

Salmonella biofilms have proven to vastly contribute to resistance to a variety of clinically important antibiotics like ciprofloxacin and quinolones. From this point, there is an interest to explore plant extracts as anti-biofilm tools to reduce the risk of disease with pathogenic microorganisms (Sakarikou et al., 2020). For example, the hydrosol of Thymbra capitate proved to be effective against Salmonella biofilm (Sakarikou et al., 2020). Burdock leaves has an anti-biofilm activity against S. typhimurium (Liu et al., 2017). More studies are needed to further examine the interaction that YM extracts might have on the different virulence factors (such as the biofilm) of different Salmonella species.

\section{Conclusion}

The discovery of antimicrobial activities of plant extracts can be considered an important step towards the development of new antimicrobial agents. While the MIC of YM does not compare to antibiotics used in the medical practice, these extracts might play a crucial role in decreasing the bacterial inoculum attenuating therefore the possibility of the infection. More work is needed to identify the antibacterial compound(s) found in YM.

\section{Limitation}

A limitation of this study is the sample size of Salmonella strains studied with different profiles of resistance. Another is the identification of bioactive compound(s) in Ilex paraguariensis.

\section{List Of Abbreviations}

Invasive Non-Typhoidal Salmonella (iNTS), Minimum Inhibitory Concentration (MIC), Mueller Hinton Agar (MHA), Mutant Prevention Concentration (MPC), Mutant Selection Window (MSW), Non-Typhoidal Salmonella (NTS), Salmonella Pathogenicity Island (SPI), Yerba mate (YM).

\section{Declarations}

\section{Ethics approval and consent to participate}

All bacterial isolates were kindly provided by the CHN hospital (Centre Hospitalier du Nord), North Lebanon. The plant samples (YM) were purchased from the local market.

\section{Consent for publication}

Not applicable. 
All the remaining data generated during this study are included in the manuscript or as Supplementary Data.

\section{Competing of Interest}

The authors declare that they have no competing interests.

\section{Funding}

The authors would like to thank the TWAS Young Affiliates Network (TYAN) that supported the travel of VD to the Lab of RAM at the University of Balamand, Lebanon through the TYAN Collaborative Grant Award F.R. 3240300824.

\section{Authors' contributions}

$\mathrm{KEK}, \mathrm{RAH}, \mathrm{AS}, \mathrm{AK}$, and EF conducted experimental procedures, data analysis and manuscript preparation. VD helped in collecting samples and in manuscript revision. RAM and ZD conceived the design of the work and were involved in the analysis and interpretation of results and provided substantial revision of the manuscript. All authors read and approved the final manuscript.

\section{Acknowledgements}

The authors would like to thank the TWAS Young Affiliates Network (TYAN) that supported the collaboration between Lebanon and Benin through the TYAN Collaborative Grant Award.

\section{References}

1. Al-Rifai, R. H., Chaabna, K., Denagamage, T., Alali, W. Q. (2020). Prevalence of non-typhoidal Salmonella enterica in food products in the Middle East and North Africa: A systematic review and meta-analysis. Food Control, 109, 106908.

2. Balasubramanian, R., Im, J., Lee, J. S., Jeon, H. J., Mogeni, O. D., Kim, J. H., Rakotozandrindrainy, R., Baker, S., Marks, F. (2019). The global burden and epidemiology of invasive non-typhoidal Salmonella Human Vaccines \& Immunotherapeutics, 15(6): 1421-1426.

3. Bastos, D. H. M., De Oliveira, D. M., Matsumoto, R. T., Carvalho, P. D. O., Ribeiro, M. L. (2007). Yerba mate: pharmacological properties, research and biotechnology. Med Aromat Plant Sci Biotechnol, 1(1): 37-46.

4. Black, J. A., Moland, E. S., Thomson, K. S. (2005). AmpC disk test for detection of plasmid-mediated AmpC $\beta$-lactamases in Enterobacteriaceae lacking chromosomal AmpC $\beta$-lactamases. Journal of Clinical Microbiology, 43(7): 3110-3113.

5. Borges, K. A., Furian, T. Q., Borsoi, A., Moraes, H. L., Salle, C. T., Nascimento, V. P. (2013). Detection of virulence-associated genes in Salmonella enteritidis isolates from chicken in South of Brazil. Pesquisa Veterinaria Brasileira, 33(12): 1416-1422. 
6. Choudhury, M., Borah, P., Sarma, H., Barkalita, L., Deka, N., Hussain, I., \& Hussain, M. (2016). Multiplex-PCR assay for detection of some major virulence genes of Salmonella enterica serovars from diverse sources. Current Science, 111(7), 1252-1258.

7. CLSI, M07, Methods for dilution antimicrobial susceptibility tests for bacteria that grow aerobically. 2018 Edition.

8. Crump, J. A., Sjölund-Karlsson, M., Gordon, M. A., Parry, C. M. (2015). Epidemiology, clinical presentation, laboratory diagnosis, antimicrobial resistance, and antimicrobial management of invasive SalmonellaClinical microbiology reviews, 28(4): 901-937.

9. Cunningham, S. A., Limbago, B., Traczewski, M., Anderson, K., Hackel, M., Hindler, J., Sahm, D., Alyanak, E., Lawsin, A., Christopher, A., Gulvik, C. A., de Man, T. J., Mandrekar, J. N., Schuetz, A. N., Jenkins, S., Humphries, R., Palavecino, E., Vasoo, S., Patel, R. (2017). Multicenter performance assessment of Carba NP test. Journal of Clinical Microbiology, 55(6): 1954-1960.

10. Dandachi, I., Sokhn, E. S., Dahdouh, E.A., Azar, E., El-Bazzal, B., Rolain, J-M., Daoud, Z. 2018. Prevalence and characterization of multi-drug-resistant Gram-Negative bacilli isolated from Lebanese poultry: A nationwide study. Frontiers in Microbiology, Frontiers Media, 9 (550), 10.3389/fmicb.2018.00550. hal-01780664.

11. De Bona, E. D. A. M., da Silva Pinto, F. G., Borges, A. M. C., Weber, L. D., Fruet, T. K., Alves, L. F. A., de Moura, A. C. (2010). Avaliação da atividade antimicrobiana de erva-Mate (Ilex paraguariensis) sobre sorovares de Salmonella de origem avícola. Journal of Health Sciences, 12(3).

12. Eng, S.-K., Pusparajah, P., Ab Mutalib, N.-S., Ser, H.-L., Chan, K.-G., Lee, L.-H. (2015). Salmonella: a review on pathogenesis, epidemiology and antibiotic resistance. Frontiers in Life Science, 8(3): 284293.

13. EUCAST, T. (2017). European Committee on Antimicrobial Susceptibility Testing, Breakpoint tables for interpretation of MICs and zone diameters. Version 10.0, 2017.

14. Fayad, E., El-Sawalhi, S., Azizi, L., Beyrouthy, M., Abdel-Massih, R. M. (2020). Yerba Mate (Ilex paraguariensis) a potential food antibacterial agent and combination assays with different classes of antibiotics. LWT - Food Science and Technology, 125: 109267.

15. Giorgio, D. (2000). Role of antibiotic therapy on long-term germ excretion in faeces and digestive symptoms after SalmonellaAlimentary Pharmacology \& Therapeutics, 14(9): 1127-1131.

16. Girolometto, G., Avancini, C. A. M., Carvalho, H. H. C., Wiest, J. M. (2009). Antibacterial activity of yerba mate (Ilex paraguariensis St.-Hil.) extracts. Revista Brasileira de Plantas Medicinais. 11(1): 4955.

17. Kungel, P. T., Correa, V. G., Corrêa, R. C., Peralta, R. A., Soković, M., Calhelha, R. C., Bracht, A., Ferreira, I. C., Peralta, R. M. (2018). Antioxidant and antimicrobial activities of a purified polysaccharide from yerba mate (Ilex paraguariensis). International Journal of Biological Macromolecules, 114: 11611167.

18. Liu, Y., McKeever, L. C., Malik, N. S. (2017). Assessment of the antimicrobial activity of olive leaf extract against foodborne bacterial pathogens. Frontiers in Microbiology, 8: 
19. Marcus, S. L., Brumell, J. H., Pfeifer, C. G., Finlay, B. B. (2000). Salmonella pathogenicity islands: big virulence in small packages. Microbes and Infection, 2(2): 145-156.

20. Martin, J. G. P., Porto, E., de Alencar, S. M., da Glória, E. M., Corrêa, C. B., Cabral, I. S. R. (2013). Antimicrobial activity of yerba mate (Ilex paraguariensis Hil.) against food pathogens. Revista Argentina de Microbiologia, 45(2): 93-98.

21. Medalla, F., Gu, W., Mahon, B. E., Judd, M., Folster, J., Griffin, P. M., Hoekstra, R. M. (2017). Estimated incidence of antimicrobial drug-resistant nontyphoidal Salmonella infections, United States, 20042012. Emerging Infectious Diseases, 23(1): 29.

22. Noureddine, T., El Husseini, Z., Nehme, A., Abdel-Massih, R. M. (2018). Antibacterial activity of Ilex paraguariensis (Yerba Mate) against Gram-positive and Gram-negative bacteria. The Journal of Infection in Developing Countries, 12(09): 712-719.

23. Pasquali, F., \& Manfreda, G. (2007). Mutant prevention concentration of ciprofloxacin and enrofloxacin against Escherichia coli, Salmonella typhimurium and Pseudomonas aeruginosa. Veterinary Microbiology, 119(2-4): 304-310.

24. Penteado, J. O., Volcão, L. M., Ramos, D. F., da Silva-Júnior, F. M., Muccillo-Baisch, A. L. (2016). Antimicrobial activity of Ilex paraguariensisJournal of Epidemiology and Infection Control, 1(1): 136146.

25. Choudhury, M., Borah, P., Sarma, H., Barkalita, L., Deka, N., Hussain, I., \& Hussain, M. (2016). Multiplex-PCR assay for detection of some major virulence genes of Salmonella enterica serovars from diverse sources. Current Science,111(7), 1252-1258.

26. Rebelo, A.R., Bortolaia, V., Kjeldgaard, J.S., Pedersen, S.K., Leekitcharoenphon, P., Hansen, I.M., et al. 2018.

27. Rebelo, A.R., Bortolaia, V., Kjeldgaard, J.S., Pedersen, S.K., Leekitcharoenphon, P, Hansen, I.M., Guerra, B., Malorny, B., Borowiak, M., Hammer, J.A., Battisti, A., Franco, A., Alba, P., Perrin-Guyomard, A., Granier, S.A., De Frutos Escobar, C., Malhotra-Kumar S., Villa, L., Carattoli, A., Hendriksen, R.S. (2018). Multiplex PCR for detection of plasmid-mediated colistin resistance determinants, mcr-1, mcr-2, mcr3 , mcr-4 and mcr-5 for surveillance purposes. Euro Surveillance: European Communicable Disease Bulletin 23(6):10.2807/1560, 7917.ES.2018.23.6.17-00672.

28. Rempe, C. S. (2016). Metabolomics approaches to decipher the antibacterial mechanisms of yerba mate (Ilex paraguariensis) against Staphylococcus aureus and Salmonella enterica serovar Typhimurium. PhD diss., University of Tennessee. Available at: http://trace.tennessee.edu/utk_graddiss/3957

29. Roschanski, N., Fischer, J., Guerra, B., Roesler, U. (2014). Development of a multiplex real-time PCR for the rapid detection of the predominant beta-lactamase genes CTX-M, SHV, TEM and CIT-type AmpCs in Enterobacteriaceae. PloS one, 9(7), e100956.

30. Sakarikou, C., Kostoglou, D., Simões, M., Giaouris, E. (2020). Exploitation of plant extracts and phytochemicals against resistant Salmonella in biofilms. Food Research International, 128, 108806. 
31. Sánchez-Vargas, F. M., Abu-El-Haija, M. A., Gómez-Duarte, O. G. (2011). Salmonella infections: an update on epidemiology, management, and prevention. Travel Medicine and Infectious Disease, 9(6): 263-277.

32. Vieitez, I., Maceiras, L., Jachmanián, I., Alborés, S. (2018). Antioxidant and antibacterial activity of different extracts from herbs obtained by maceration or supercritical technology. The Journal of Supercritical Fluids, 133: 58-64.

33. Wen, S. C., Best, E., Nourse, C. (2017). Non-typhoidal Salmonella infections in children: Review of literature and recommendations for management. Journal of Paediatrics and Child Health, 53(10): 936-941.

\section{Supplementary Files}

This is a list of supplementary files associated with this preprint. Click to download.

- TableS1BMC.docx

- Tables1BMC.docx 